\title{
Spelling errors in official letters in the Ciracas area East Jakarta
}

\author{
Sri Mulyani*), \\ Universitas Indraprasta PGRI \\ *) Correspondences author: Jalan Nangka 58 Tanjung Barat, Jakarta Selatan; Indonesia \\ e-mail: srimulyani.unindra@gmail.com
}

\begin{abstract}
The purpose of this research is to describe spelling errors in the official letter in ciracas area, East Jakarta written since February ---- November 2017 while the method used in this research, that is descriptive qualitative. Data collection techniques by collecting six letters of service. After research on six official letters from the "Suci" Islamic Foundation, Al-Hidayah educational institutions, Adhiluhur Mahadika Foundation, Madrasah High School Mahadika, Fathurahman Mosque prosperity Council, and PT PLN in Ciracas region, resulted in erroneous spelling of Indonesian ( EBI) in total amounted to 32 findings relating to the writing of abbreviations amounted to 8 findings or $25 \%$, the composite word writing amounted to 5 findings or $15.62 \%$, the use of punctuation marks 9 findings or $28.12 \%$, writing absorption element 2 findings or $6,25 \%$, letter writing amounted to 4 finding or $4.12 \%$, and word writing gamounted to 4 finding or $12.5 \%$. From this finding, it was concluded that the bigges spelling use error in the official letter on the use punctuation is $28,12 \%$.
\end{abstract}

Key Words: letter of service, spelling, and language

Article History: Received: 22/06/2018; Revised: 27/07/2018; Accepted: 19/08/2018; Published: 22/08/2018

How to Cite (MLA $7^{\text {th }}$ ): Mulyani, Sri. "Spelling errors in official letters in the Ciracas area East Jakarta." Hortatori Jurnal Pendidikan Bahasa dan Sastra Indonesia 2.1 (2018): 57-68. Print/Online. Copyrights Holder: Mulyani, Sri. First Publication: Hortatori Jurnal Pendidikan Bahasa dan Sastra Indonesia (2018).

\section{Pendahuluan}

Dalam kehidupan sehari-hari, manusia tidak terlepas dari saling memberi informasi, baik secara lisan maupun tulis. Informasi secara lisan terjadi jika pemberi informasi berhadap-hadapan dengan penerima. Pemberian informasi melalui telepon, radio, dan televisi termasuk pemberian informasi secara lisan, sedangkan Informasi secara tertulis terjadi jika pemberi informasi tidak mungkin berhadap-hadapan dengan penerima. Informasi ini tidak mungkin menggunakan media seperti tertera di atas, karena sarana komunikasi tertulis untuk menyampaikan informasi kepada orang lain atau instansi lain itu terdiri atas beberapa macam, salah satu diantaranya adalah surat.

Jika dibandingkan dengan alat komunikasi yang lain, surat memiliki kelebihan, yaitu dapat mengurangi kesalahpahaman dalam komunikasi, karena penulis dapat menyampaikan maksud dengan sejelas-jelasnya. Sebagai sarana komunikasi tertulis, sebaiknya surat menggunakan bentuk yang menarik, tidak terlalu panjang, dan memakai bahasa yang jelas, padat, adab, dan takzim sedangkan bentuk surat dikatakan menarik jika letak bagian-bagian surat tidak ditempatkan secara sembarangan menurut keinginan penulis.

Surat diusahakan tidak panjang karena surat yang panjang dan bertele-tele akan menbosankan. Selain itu, bahasa surat dikatakan jelas jika maksudnya mudah dipahami dan unsur-unsur gramatikal seperti subjek dan predikat dinyatakan secara tegas, serta tanda-tanda baca digunakan dengan tepat. Bahasa surat dikatakan padat jika langsung mengungkapkan pokok pikiran yang ingin disampaikan. Bahasa surat dikatanya adab jika pernyataan yang dikemukakan itu sopan. 
Menurut Sedarmayanti (2001: 162), "surat merupakan suatu media untuk menyampaikan berita". Setiawan Djuhari, dkk. (2001) mengatakan "surat merupakan komunikasi tertulis untuk menyampaikan informasi pernyataan, pesan kepada pihak lain yang mempunyai keperluan kegiatan dengan berbagai pihak tertentu". Informasi yang disampaikan secara tertulis dalam surat dapat berbentuk pernyataan, undangan, pemberitahuan, pertanyaan, permintaan, dan lain-lain. Informasi akan mencapai sasaran jika bahasa yang digunakan dapat mengungkapkan isi surat sesuai dengan sifat surat serta kedudukan penulis dan pembaca surat. Dengan membaca beberapa surat dinas di wilayah Ciracas menunjukkan bahwa surat yang ditulis belum sesuai dengan kaidah kebahasaan yang baik dan tepat.

Atas dasar itu, para penulis surat perlu meningkatkan kemampuan dan pemahaman terhadap penggunaan ejaan dalam menulis surat dinas. Menurut Arifin (2008: 164) "ejaan merupakan keseluruhan peraturan dalam melambangkan bunyi ujaran dan hubungan antara lambang-lambang bahasa", sedangkan Suyanto (2011: 90) ejaan adalah ilmu yang mempelajari ucapan yang dilisankan oleh seseorang dengan perantara lambang-lambang atau gambar-gambar bunyi. Sejarah ejaan yang pernah berlaku di Indonesia sudah beberapa kali mengalami penyempurnaan dari ejaan Van Ophusyen, Republika, EYD, hingga PUEBI yang pada tahun 2016 berdasarkan Keputusan Menteri Pendidikan dan Kebudayaan, Dr. Anis Baswedan menjadi Pedoman Umum Ejaan Bahasa Indonesia (PUEBI) yang penyempurnaan naskahnya disusun oleh Pusat Pengembangan dan Pelindungan dan Pembinaan Bahasa. Cakupan PUEBI membahas mengenai 1) pemakaian huruf meliputi huruf abjad, huruf vocal, huruf konsonan, huruf diftong, gabungan huruf konsonan, huruf kapital, huruf miring, dan huruf tebal. 2) Penulisan kata meliputi kata dasar, kata berimbuhan, bentuk ulang, gabungan kata, pemenggalan kata, kata depan, partikel, singkatan dan akronim, angka dan bilangan, kata ganti ku-, kau-, -ku, -mu, -nya, dan kata sandang. 3) Pemakaian tanda baca meliputi tanda titik (.), tanda koma (,), tanda titik dua (:), tanda hubung (-), tanda pisah (--- ), tanda tanya (?), tanda seru (!), tanda ellipsis (...), tanda petik (“...”), tanda petik tunggal ('..'), tanda kurung ((..)), tanda kurung siku ([...]), tanda garis miring (/), dan tanda penyingkat atau apostrof( $\left.{ }^{\circ}\right)$, dan 4) Penulisan unsur serapan. Hal inilah yang harus diperhatikan dalam bahasa tulis.

Bahasa adalah suatu sistem simboll yang digunakan untuk komunikasi dengan orang lain. Selain itu, bahasa merupakan suatu alat komunikasi yang digunakan melalui suatu sistem, kata, pola yang digunakan manusia untuk menyampaikan pertukaran pikiran dan perasaan, maka gunakan bahasa yang baik dan tepat. Bahasa yang baik adalah bahasa Indonesia yang digunakan sesuai dengan situasi komunikasi, baik situasi resmi dan tidak resmi maupun situasi siapa yang diajak berkomunikasi. Bahasa yang tepat adalah bahasa yang digunakan sesuai dengan kaidah bahasa, sedangkan bahasa yang baik dan tepat adalah bahasa Indonesia yang digunakan sesuai dengan situasi dan mengacu pada kaidah kebahasaan. Seperti contoh dalam menulis surat dinas.

Surat dinas merupakan sarana komunikasi resmi, bahasa yang digunakanpun harus bahasa Indonesia yang mampu mencerminkan keresmian, yaitu bahasa yang beragam baku. Ragam baku adalah ragam standar atau ragam yang sesuai dengan kaidah. "Surat adalah sarana untuk menyampaikan pernyataan atau informasi secara tertulis dari pihak satu kepada pihak yang lain", (H. Muktar, 2000: 1), sedangkan dalam KBBI (2014: 1361) "surat adalah salah satu kegiatan bahasa yang dilakukan dengan interaksi tulis (berkirim-kiriman surat, tulis-menulis surat, korespondensi).

Dengan demikian, kajian yang relevan dengan penelitian ini adalah Analisis Kesalahan Penggunaan Ejaan pada Surat Dinas Kantor Camat Kecamatan Sabil Kabupaten Aceh Barat Daya disusun oleh Sumarni (2013), Kesalahan Penggunaan Ejaan Surat Dinas di SDN Dinoyo Lamongan disusun oleh Emalia Nova Sustyorini (2013), dan Kesalahan Ejaan pada Surat Dinas di Balai Desa Butuh Krajan. Implementasi Undang-Undang No.24 Tahun 2009, yaitu sebagai bahasa yang wajib digunakan dalam dokumen resmi Negara ( Pasal 27) dan dalam komunikasi resmi di lingkungan kerja pemerintah dan swasta ( Pasal 33). Selain itu, sebagai sarana penyampaian informasi dalam komunikasi kedinasan, termasuk dalam tata naskah dinas.

Naskah dinas adalah informasi tertulis sebagai alat komunikasi kedinasan yang dibuat dan/atau dikeluarkan oleh pejabat yang berwenang. Sebagai dokumen resmi, naskah dinas termasuk di dalamnya surat dinas, harus ditulis dengan menggunakan bahasa Indonesia yang memenuhi kriteria secara baik dan tepat, efektif, efisien, serta lugas dan eksplisit. 
Berdasarkan uraian di atas, maka tujuan penelitian ini untuk mengetahui penggunaan ejaan pada surat dinas di wilayah Ciracas.

\title{
Metode
}

Penelitian ini menggunakan metode deskriptif kualitatif, sedangkan sumber data penelitian ini adalah enam buah surat dinas yang berasal dari Yayasan Islam "Suci", lembaga pendidikan Al-Hidayah, Yayasan Adhiluhur Mahadika Sekolah Menengah Kejuruan Mahadika, Dewan Kemakmuran Masjid Fathurahman, dan PT PLN sejak Februari ---- November 2017, di wilayah Ciracas, Jakarta Timur, sedangkan fokus penelitian ini pada kesalahan penulisan ejaan ini meliputi penulisan huruf, penulisan kata, pemakaian tanda baca, dan penulisan unsur serapan.

Moleong (2010: 6) menyatakan penelitian kualitatif adalah penelitian yang bermaksud untuk memahami fenomena yang diperoleh peneliti.

\section{Hasil dan Diskusi}

Bagian ini memaparkan hasil analisis penggunaan ejaan pada surat dinas yang berasal dari lembaga pendidikan, dewan kemakmuran masjid, dan PT PLN.

\section{A. Data I dari Yayasan Islam Suci}

YAYASAN ISLAM SUCI

Jl. Suci Kel. Susukan Kec. Ciracas Jakarta Timur 13750

Telp.021-87796166

Analisis:

Pada kepala surat (Kop surat) di atas terdapat kesalahan penulisan singkatan Jl. Berdasarkan PUEBI penulisan singkatan yang benar, yaitu Jln. Untuk menjaga keamanan dari makna lain, maka Jl. lebih aman tidak perlu disingkat.

\author{
Kepada TYH \\ Bapak/Ibu Orangtua Siswa \\ SDI Teladan Suci \\ Di Tempat
}

\section{Analisis:}

Penggunaan alamat surat di atas terdapat kesalahan singkatan YTH

Merujuk pada PUEBI penulisan yang tepat, yaitu Yth.

Demi kecermatan berbahasa, tidak perlu Kepada digunakan, karena tanpa digunakan kata kepada pun alamat surat yang dimaksud sudah jelas. Dalam hal itu, cukup mengunakan frase Yang terhormat yang disingkat Yth.

Sehubungan dengan jumlah siswa yang semakin banyak di lingkungan SDI Teladan Suci, dalam hal menertibkan administrasi SPP kami menghimbau kepada Bapak/Ibu Orangtua siswa untuk mengisi lembar persetujuan SPP ONLINE (melalui Bank/ATM).

Analisis: 
Penulisan kata di atas terdapat kesalahan gabungan kata, yaitu orangtua. Merujuk pada PUEBI penulisan gabungan kata yang benar, yaitu orang tua ditulis pisah, karena unsur gabungan kata tersebut kata majemuk.

Sehubungan dengan jumlah siswa yang semakin banyak di lingkungan SDI Teladan Suci, dalam hal menertibkan administrasi SPP kami menghimbau kepada Bapak/Ibu Orangtua Siswa untuk mengisi lembar persetujuan SPP ONLINE (melalui Bank/ATM).

Analisis:

Penulisan unsur serapan di atas salah. Mengacu pada PUEBI penulisan unsur serapan yang benar, yaitu Online ditulis miring, karena kata tersebut merupakan kata asing, tiap kata asing yang melekat dalam kalimat bahasa Indonesia ditulis miring dengan tujuan untuk membedakan bahasa Indonesia dan unsur asing.

Jakarta, 11 September 2017

Badan Pelaksana Harian

Ketua Umum

Gajah Nata Surya Candra, M.M

Analisis:

Penulisan gelar pada jabatan penanda tangan terdapat kesalahan penulisan tanda baca, yaitu M.M

Mengacu pada PUEBI penulisan gelar yang benar, yaitu M.M. karena huruf kapital dipakai sebagai huruf pertama unsur singkatan nama gelar yang diikuti dengan tanda titik pada setiap unsure singkatan.

Berdasarkan hasil penelaahan terhadap surat dinas dari Yayasan Islam Suci, terdapat kesalahan penggunaan ejaan yang berkaitan penggunaan singkatan sejumlah 2 temuan, kesalahan penggunssn gabungan kata sejumlah 1 temuan, kesalahan penggunaan unsur serapan sejumlah 1 temuan, dan kesalahan pemakaian tanda baca pada gelar seseorang sejumlah 1 temuan. Jadi, total kesalahan penulisan ejaan pada surat dinas di atas, yaitu 5 temuan.

\section{B. Data 2 Surat Dinas dari Lembaga Pendidikan Sekolah Dasar Teladan Suci \\ YAYASAN ISLAM SUCI \\ SD ISLAM TELADAN SUCI}

Jl. Suci Kel. Susukan Kec. Ciracas Jakarta Timur 13750

Telp.021- 87796166

NIS: 100660

NSPN: 20104296

Analisis:

Kepala surat (Kop surat) di atas terdapat kesalahan penggunaan singkatan Jl. dan letak tanda baca di depan NIS, NSPN. Merujuk pada PUEBI penulisan yang benar, yaitu Jln. Untuk menjaga keamanan dari makna lain, maka Jl. lebih aman tidak perlu disingkat, sedangkan letak tanda titik dua di depan (:), yaitu NIS dan NSPN dihilangkan dan diikuti nomor tanpa jarak, karena NIS dan NSPN bukan nama diri. 
Kepada Yth,

Wali Murid Kelas I s/d II

SDI Teladan Suci

Di Jakarta

Analisis:

Penulisan alamat surat di atas salah, karena menggunakan kepada dan pemakaian tanda baca di depan Yth, (koma).

Merujuk pada PUEBI penulisan alamat surat yang tepat tidak menggunakan kepada, karena kepada dan Yth. memiliki tujuan yang sama. Oleh karena itu, kepada tidak digunakan, karena tujuan itu sudah jelas, sedangkan pemakaian tanda baca di depan singkatan Yth yang benar adalah tanda baca titik (.) bukan koma (,), karena singkatan tersebut terdiri atas tiga huruf. Tanda baca koma (,) dipakai di antara unsur-unsur dalam suatu pemerincian atau pembilangan.

Kepada Yth,

Wali Murid Kelas I s/d II

SDI Teladan Suci

Di Jakarta

Analisis:

Penggunaan singkatan s/d pada alamat surat di atas salah. Merujuk pada PUEBI penulisan singkatan yang benar adalah s.d., karena singkatan tersebut terdiri atas dua huruf yang lazim dipakai dalam suratmenyurat dan tiap huruf diikuti oleh tanda titik (.) masing-masing.

Berkenaan dengan program sekolah, yaitu Field Trip dan Out Bond, bersama ini kami sampaikan bahwa Field Trip dan Out Bond kelas I s/d II akan dilaksanakan pada:

Analisis:

Penulisan kata unsur serapan pada kalimat di atas salah, yaitu Field Trip dan Out bond.

Mengacu pada PUEBI penulisan kata serapan yang benar adalah Field Trip dan Out Bond ditulis miring, karena kata tersebut berasal dari bahasa asing. Tujuan ditulis miring untuk membedakan antara bahasa Indonesia dengan bahasa Inggris.

Berkenaan dengan program sekolah, yaitu Field Trip dan Out bond, bersama ini kami sampaikan bahwa Field Trip dan Out bond kelas I s/d II akan dilaksanakan pada:

Hari/Tanggal : Kamis/23 Maret 2017

Tujuan Wisata : Pelita Village, Ciseeng-Bogor Jawa Barat

Biaya $\quad:$ Rp480.000, 00/siswa dan orang tua.

Analisis:

Penulisan perincian di atas salah, yaitu pada penulisan huruf: Hari/Tanggal, Tujuan Wisata, dan Biaya. Merujuk pada PUEBI penulisan bentuk perincian untuk mengawali kata hari/tanggal, tujuan wisata, dan biaya adalah dengan huruf kecil, karena kata-kata tersebut termasuk dalam unsur-unsur perincian yang harus diselesaikan.

Jakarta, 16 Februari 2017 
Ketua panitia

Jalu Prio Kusumo, S.Sn

Sekretaris

Efy Widianti, S.Pd

Mengetahui

Kepala Sekolah

Abdul Aziz, M.Si

Analisis:

Penulisan gelar pada orang yang bertanggung jawab pada surat di atas salah, yaitu pada tanda baca S.Sn, S.Pd, dan M.Si

Merujuk pada PUEBI penulisan gelar yang benar adalah S.Sn., S.Pd., dan M. Si., karena penulisan singkatan gelar melekat di belakang nama seseorang yang diikuti dengan tanda titik.

Berdasarkan hasil penelaahan terhadap surat dinas dari Lembaga Pendidikan Yayasan Islam Suci, penulisan kesalahan ejaan yang berkaitan dengan penulisan singkatan sejumlah 2 temuan, penulisan unsur serapan sejumlah 1 temuan, pemakaian tanda baca sejumlah 3 temuan, dan penulisan huruf kapital sejumlah 3 temuan, Jadi, total kesalahan penulisan ejaan pada data II yaitu 7 temuan.

\title{
C. Data 3 Surat Dinas dari SMK Mahadhika Jakarta
}

\author{
YAYASAN ADHILUHUR MAHADHIKA \\ SEKOLAH MENENGAH KEJURUAN (SMK) MAHADHIKA I
}

JAKARTA

STATUS: TERAKREDITASI "A"

KELOMPOK: BISNIS DAN MANAJEMEN

Kampus A: JI. Raya Centek No.29-31, Ciracas, Telp/Fax. (021)87707179, Jakarta Timur 13740

Analisis:

Penulisan singkatan Jl. pada kepala surat di atas salah. Merujuk pada PUEBI bahwa penulisan singkatan Jl. yang benar adalah Jln., Untuk menjaga keamanan dari makna lain, maka Jl. lebih aman tidak perlu disingkat atau ditulis secara lengkap Jalan.

\section{Kepada}

Yth. Bapak/Ibu Wali Murid Kelas X

Program Akuntansi dan Adm. Perkantoran

SMK Mahadhika I Jakarta

Analisis: 
Penulisan alamat surat di atas salah yaitu kepada Yth.

Mengacu pada PUEBI penulisan alamat surat yang benar adalah

Yth. Bapak/Ibu Wali Murid Kelas X

Program Akuntasi dan Adm. Perkantoran SMK Mahadhika I Jakarta tanpa menggunakan kepada pun alamat surat yang dimaksud sudah jelas. Dalam hal itu, cukup mengunakan frase Yang terhormat yang disingkat Yth.

Dengan hormat, kami mengharap kehadiran Bapak/Ibu Orang Tua/Wali Murid kelas X SMK Mahadhika I Jakarta pada:

Hari/Tanggal: Senin/10 Juli 2017

Pukul : 09.00 s.d. selesai

Acara : Rapat Pengarahan dan Perkenalan SMK Mahadhika I Jakarta

Tempat : Lantai 3 Gedung SMK Mahadhika I Jakarta Jln. Raya Centex No.29-31 Ciracas Jakarta Timur Telp.87707179.

Analasis:

Penulisan perincian pada Hari/Tanggal, Pukul, Acara, dan Tempat di atas salah.

Merujuk pada PUEBI, bahwa penulisan bentuk perincian yang tepat diawali dengan huruf kecil, yaitu hari/tanggal, pukul, acara, dan tempat, karena perincian tersebut lanjutan dari kalimat pemerian di atas yang harus diselesaikan dengan $\operatorname{diakhiri} \operatorname{titik}($.

Jakarta, 6 Juli 2017

Kepala Sekolah Mahadhika I

\section{H. AGUS SURYANI, S.Ag, M. Pd}

Analisis:

Penulisan tanda baca pada gelar seseorang di atas salah, yaitu M.Pd

Merujuk pada PUEBI, bahwa penulisan gelar yang tepat adalah H. AGUS SURYANI, S.Ag., M.Pd. karena gelar itu melekat di belakang nama seseorang dan diikuti dengan tanda titik (.) pada tiap unsur singkatan.

Berdasarkan penelaahan terhadap surat dinas dari SMK Mahadhika, terdapat kesalahan penulisan ejaan, yaitu penulisan singkatan sejumlah 1 temuan, penulisan kata sejumlah 1 temuan, pemakaian tanda baca sejumlah 1 temuan, dan penulisan huruf sejumlah 1 temuan. Jadi, total kesalahan penulisan ejaan pada surat dinas di atas, yaitu 4 temuan.

\section{Data 4 Surat Dinas dari Lembaga Pendidikan Al-Hidayah}

LEMBAGA PENDIDIKAN “AL-HIDAYAH”

Akta Notaris No.215/X-2001 IzinDepag No. W3/3-d/BA-01.1/7193/2001

MENYELENGGARAKAN:

1. TAMAN KANAK-KANAK AL-QUR'AN (TKA)

2. TAMAN PENDIDIIKAN AL-QUR'AN (TPA)

3. MADRASAH DINIYAH TAKMILIYA (MDIT)

4. BIMBINGAN BELAJAR AL-QUR'AN

Sekretariat: Jl. Dewa Ujung Rt.12/07 Ciracas Jakarta Timur Telp.(021)8713018 
Analisis:

Penulisan Kop Surat di atas terdapat kesalahan penulisan pada singkatan, yaitu Jl.

Merujuk PUEBI, bahwa penulisan yang benar dalam menulis singkatan Jl. adalah Jln. terdiri atas tiga huruf agar tidak terjadi salah makna.

\section{Kepada}

Yth. Bapak/Ibu Wali Santri

Lembaga Pendidikan Al-Hidayah

Di tempat

Analisis:

Penulisan alamat surat di atas salah, yaitu kepada Yth.

Merujuk pada PUEBI, bahwa penulisan alamat surat yang benar tidak menggunakan kepada, cukup Yth. Bapak/Ibu Wali Santri Lembaga Pendidikan Al-Hidayah di tempat karena tanpa menggunakan kepada alamat surat yang dimaksud sudah jelas. Dalam hal itu, cukup mengunakan frase Yang terhormat yang disingkat Yth.

Sehubungan akan berakhirnya kegiatan belajar mengajar dalam semester I, tahun pelajaran 2017/2018.

Analisis:

Penulisan isi surat di atas terdapat kesalahan pemakaian tanda baca, yaitu garis miring pada tahun 2017/2018. Merujuk PUEBI, bahwa penulisan tahun pelajaran yang tepat adalah 2017-_-2018 menggunakan tanda pisah, karena menyatakan dua bilangan yang berarti ' sampai dengan' atau 'sampai ke'.

Kegiatan testing/Ulangan Umum (ULUM) untuk kelas TKA, TPA dan MDT tanggal 11 Desember s/d 14 Desember 2017.

Analisis:

Penulisan isi pemberitahuan pada surat di atas salah, yaitu pemakaian tanda baca sebelum dan, dan penulisan tanda baca $\mathbf{s} / \mathbf{d}$.

Merujuk pada PUEBI, bahwa penulisan perincian yang benar adalah Kegiatan testing/Ulangan Umum (ULUM) untuk kelas TKA, TPA, dan MDT tanggal 11 Desember s.d. 14 Desember 2017, karena singkatan tersebut terdiri atas dua huruf dan tiap-tiap huruf diikuti oleh tanda titik (.).

Bagi santri yang belum mengumpulkan raport dan pas foto, ukuran $3 \times 4$ sebanyak 4 lembar (berwarna), diharapkan segera untuk mengumpulkannya.

Analasis:

Isi pemberitahuan pada surat di atas salah. Pada penulisan bagi dan pas foto.

Merujuk pada PUEBI, penulisan kata bagi di atas tidak tepat karena bagi memiliki makna pembagian mata ilmu matematika, sehingga bagi pada awal kalimat ditiadakan untuk menghindari makna lain. Penulisan gabungan kata yang pasfoto ditulis serangkai, karena gabungan itu terdiri atas dua unsur dan salah satu unsur itu dapat bergabung dengan unsur lain. 
Demikianlah surat pemberitahuan ini kami sampaikan, atas perhatiannya kami ucapkan terima kasih.

Analisis:

Penulisan kalimat penutup surat di atas salah yaitu perhatiannya.

Merujuk pada PUEBI, penulisan sapaan yang benar adalah atas perhatian Bapak/Ibu/Saudara kami ucapkan terima kasih, karena nya merupakan sapaan yang merujuk pada alamat surat di atas.

Berdasarkan penelaahan terhadap surat dinas dari Lembaga Pendidikan Al-Hidayah, terdapat kesalahan penggunaan ejaan, yaitu penulisan singkatan sejumlah 2 temuan, kesalahan penulisan kata sejumlah 2 temuan, pemakaian tanda baca sejumlah 2 temuan, dan penulisan gabungan kata sejumlah 1 temuan. Jadi, total kesalahan penggunaan ejaan pada data 4, yaitu 7 temuan.

\title{
E. Data 5 Surat dari Dewan Kemakmuran Masjid Faturrahman
}

\author{
Dewan kemakmuran masjid Fatturrahman
}

Jl. H. Baping, Gang TK RT002/009, Ciracas, Jakarta Timur

Telp. 081317979264

\section{Analisis:}

Penulisan singkatan Jl. pada kepala surat di atas salah. Merujuk pada PUEBI, penulisan singkatan Jl. yang benar adalah Jln. Untuk menjaga keamanan dari makna lain, maka Jl. lebih aman tidak perlu disingkat.

\section{Kepada}

Yth. Bapak/Ibu Nurkholis

Di tempat

Analisis:

Penulisan alamat surat di atas salah karena menggunakan kepada.

Merujuk pada PUEBI, demi kecermatan berbahasa, tidak perlu Kepada digunakan, karena tanpa kepada pun alamat surat yang dimaksud sudah jelas. Dalam hal itu, cukup mengunakan frase Yang terhormat yang disingkat Yth. Oleh karena itu, alamat surat yang tepat berikut ini.

Yth. Bapak/Ibu Nurkholis

Di tempat

Atas perhatian dan kerjasama Bapak/Ibu, kami ucapkan Jazakumallahu Khairan Katsiran.

Analisis:

Penulisan kata kerjasama pada penutup surat di atas salah. Penulisan kata kerjasama yang tepat, merujuk pada PUEBI, ditulis pisah, yaitu kerja sama karena gabungan kata itu terdiri atas dua unsur yang tidak terikat, sehingga kalimat di atas perbaikan adalah Atas perhatian dan kerja sama Bapak/Ibu, kami ucapkan Jazakumallahu Khairan Katsiran.

Berdasarkan penelaahan terhadap data 5, surat dari Dewan Kemakmuran Masjid Faturrahman terdapat kesalahan penggunaan ejaan, yaitu penulisan singkatan sejumlah 1 temuan, penulisan kata sejumlah 1 temuan, dan penulisan gabungan kata sejumlah 1 temuan. Jadi, total kesalahan penulisan ejaan pada surat dinas di atas, yaitu 3 temuan. 


\section{F. Data 6 Surat Dinas dari PT PLN (Persero)}

Dalam rangka peningkatan pelayanan dan keandalan jaringan listrik, maka kami beritahukan aliran listrik di tempat tinggal atau perusahaan Saudara akan mengalami pemadaman sementara pada:

Analisis:

Penulisan kata beritahukan pada isi pemberitahuan pada surat di atas salah. Mengacu pada PUEBI, penulisan beritahukan yang tepat, adalah beri tahukan, karena gabungan kata itu terdiri atas dua unsur yang tidak terikat menjadi satu, kecuali jika kata tersebut mendapatkan awalan dan akhiran, sehingga dapat ditulis diberitahukan. Perbaikannya sebagai berikut.

Dalam rangka peningkatan pelayanan dan keandalan jaringan listrik, maka kami beri tahukan aliran listrik di tempat tinggal atau perusahaan Saudara akan mengalami pemadaman sementara pada:

Dalam rangka peningkatan pelayanan dan keandalan jaringan listrik, maka kami beritahukan aliran listrik di tempat tinggal atau perusahaan Saudara akan mengalami pemadaman sementara pada:

$\begin{array}{ll}\text { Hari } & \text { : Selasa } \\ \text { Tangga } & : 11 \text { Oktober 2017 s/d selesai } \\ \text { Pukul } & : \text { 08.00 s/d selesai } \\ \text { Pekerjaan } & \text { : REKONEKTORISASI JTR dan SR } \\ \text { Pelaksana } & \text { : PT. Laskar CIPTA UTAMA } \\ \text { Pengawas pekerjaan } & \text { : EDWAR } \\ \text { Koordinator lapangan } & \text { : P.Soleh } \\ \text { No Telp } & : 081293157176\end{array}$

Analisis:

Penulisan perincian di atas salah pada penulisan huruf, yaitu Hari, Tanggal, Pukul, Pekerjaan, Pelaksana, Pengawas pekerjaan, Koordinator lapangan, dan No Telp

Mengacu pada PUEBI, penulisan bentuk perincian di atas yang tepat adalah hari, tanggal, pukul, pekerjaan, pelaksana, pengawas pekerjaan, koordinator lapangan, dan No telp

dengan diawali huruf kecil kecuali jika kata-kata itu disusun secara mendatar. Maka tiap rincian diberi koma dan harus diselesaikan.

$\begin{array}{ll}\text { Tanggal } & : 11 \text { Oktober } 2017 \mathrm{~s} / \mathbf{d} \text { selesai } \\ \text { Pukul } & : 08.00 \mathbf{s} / \mathbf{d} \text { selesai }\end{array}$

Analisis:

Singkatan s/d pada kalimat di atas salah karena tidak sesuai dengan PUEBI, penulisan singkatan yang benar adalah s.d., karena bentuk singkatan ini terdiri atas dua huruf, tiap huruf diikuti tanda titik (.), sehingga penulisannya sebagai berikut.

$\begin{array}{ll}\text { tanggal } & : 11 \text { Oktober } 2017 \text { s.d. selesai } \\ \text { pukul } & : 08.00 \text { s.d. selesai }\end{array}$


No Telp : : 081293157176

Analisis:

Penulisan tanda baca pada PT. di atas salah. Merujuk pada PUEBI, penulisan PT yang tepat adalah PT tanpa diikuti titik, karena PT merupakan singkatan nama perusahaan yang terdiri atas huruf awal kata ditulis dengan huruf kapital, sehingga menjadi PT LASKAR CIPTA UTAMA

No Telp : 081293157176

Analisis:

Penulisan No Telp di atas terdapat kesalahan pada pemakaian tanda baca.

Sesuai PUEBI, penulisan singkatan No Telp yang benar, yaitu No. diikuti tanda titik(.) dan telp. diikuti tanda titik (.), sehingga menjadi No.telp. 081293157176

Pelanggan yang mengalami pemadaman adalah sebagai berikut:

Gardu: GD 402

Alamat: Jln. Raya Centek

Analisis:

Penulisan huruf kapital apa Gardu dan alamat di atas salah karena gardu dan alamat merupakan pemerian. Sehingga mengacu pada PUEBI, penulisan bentuk perincian di atas yang benar adalah gardu dan alamat diawali huruf kecil.

Berdasarkan penelaahan terhadap surat dinas dari PT PLN terdapat kesalahan penulisan ejaan, yaitu singkatan sejumlah 1 temuan, huruf sejumlah 2 temuan, dan gabungan kata sejumlah 1 temuan, dan pemakaian tanda baca sejumlah 2 temuan. Jadi, total kesalahan penulisan ejaan pada data 6 , surat dari PT PLN terdapat 6 temuan.

\section{Simpulan}

Setelah dilakukan penelitian terhadap enam surat dinas dari Yayasan Islam Suci, Lembaga Pendidikan Sekolah Dasar Islam Teladan Suci, Lembaga Pendidikan Al-Hidayah, Dewan Kemakmuran Masjid, dan PT PLN, diperoleh hasil, kesalahan penulisan ejaan bahasa Indonesia (PUEBI) secara keseluruhan sejumlah 32 temuan yang berkaitan dengan penulisan singkatan sejumlah 8 temuan atau $25 \%$, penulisan gabungan kata sejumlah 5 temuan atau 15,62\%, pemakaian tanda baca sejumlah 9 temuan atau $28,12 \%$, penulisan unsur serapan 2 temuan atau $6,25 \%$, penulisan huruf sejumlah 4 temuan atau $12,5 \%$, dan penulisan kata sejumlah 4 temuan atau $12,5 \%$. Kesalahan penulisan ejaan pada surat dinas di wilayah Ciracas yang tertinggi pada penulisan tanda baca, yaitu 9 temuan atau $28,12 \%$.

\section{Ucapan Terima Kasih}

Terima kasih penulis ucapkan kepada pihak Yayasan Islam Suci, Lembaga Pendidikan Sekolah Dasar Islam Teladan Suci, Lembaga Pendidikan Al-Hidayah, Dewan Kemakmuran Masjid, dan PT PLN yang telah membantu penulis dalam menyelesaikan penelitian ini.

\section{Daftar Rujukan}

Arifin, Zaenal. Cermat Berbahasa Indonesia untuk Perguruan Tinggi. Jakarta: Akademika Pressindo, (2004). Print 
Arifin, Zainal dan Amran Tasai. Bahasa Indonesia sebagai Mata Kuliah Perkembangan Kepribadian. Jakarta: Pustaka Mandiri, (2012). Print

Direktorat Pembinaan PTK Dikmen Kemdikbud. Bahan Ajar Mata Pelajaran Keterampilan Menulis. Bandung: Sekolah Pascasarjana UPI, (2012). Print.

Djalal, Muktar. Korespondensi Bahasa Indonesia. Jakarta: Departemen Pendidikan dan Kebudayaan, (2000). Print.

Ekoputranti, Rini Adiati. Bahan Calon Penyuluh: Penggunaan Bahasa Indonesia dalam Surat Dinas. Jakarta: Pusat Pembinaan Badan Pengembangan dan Pembinaan Bahasa, (2016). Print

Husein dan Eni Rita Zahara. Bahasa Indonesia (siap Tuntas Menghadapi Ujian Nasional). Jakarta: Erlangga, (2009). Print.

Kementerian Pendidikan dan Kebudayaan. Peraturan Menteri Pendidikan dan Kebudayaan Republik Indonesia, No.74 Tahun 2015 tentang Tata Naskah Dinas. Jakarta, (2015). Print.

Moleong, Lexy. Metodologi Penelitian Kualitatif. Bandung: Remaja Rosadakarya, (2010). Print.

Pusat Pengembangan dan Pembinaan Bahasa. KBBI Edisi empat Departeman Pendidikan Nasional. Jakarta: Gramedia Utama, (2014). Print.

Sedarmayanti. Dasar-dasar Pengetahuan Tentang Manajemen Perkantoran, Edisi Revisi. Bandung: CV Mandar Maju, (2001). Print

Setiawan Djuharie, dkk. Surat Menyurat Serbaguna. Bandung: Djambatan, (2001). Print

Sriyanto. Ejaan. Jakarta: Pusat Pembinaan Badan Pengembangan dan Pembinaan Bahasa Kementerian Pendidikan dan Kebudayaan, (2016). Print. 